\title{
Contained and uncontained morcellation in hysterectomy and myomectomy: A systematic review and meta-analysis
}

\section{Histerektomi ve miyomektomide contained ve uncontained morselasyonun sistematik derlemesi ve meta-analizi}

\author{
(1) Greg Marchand ${ }^{1}$, (1) Ahmed Masoud ${ }^{2}$, (1) Ashley Christensen ${ }^{3}$, (1) Stacy Ruther ${ }^{1}$, (1) Giovanna Brazil ${ }^{1}$, \\ (1) Alexa King ${ }^{4}$, (1) Hollie Ulibarri ${ }^{1}$, (1) Julia Parise ${ }^{1}$, (1) Amanda Arroyo ${ }^{1}$, (1) Catherine Coriell1 ${ }^{1}$, (1) Sydnee Goet $z^{1}$, \\ (1) Katelyn Sainz ${ }^{1}$
}

${ }^{1}$ Marchand Institute for Minimally Invasive Surgery, Mesa, Arizona, USA

${ }^{2}$ Fayoum University Faculty of Medicine, Fayoum, Egypt

${ }^{3}$ Midwestern University College of Osteopathic Medicine, Glendale, Arizona, USA

${ }^{4}$ International University of Health Sciences, Basseterre, St. Kitts

\begin{abstract}
We sought to analyze all high-quality studies available regarding the possible differences in contained and uncontained techniques for morcellation of fibroids and uteri. We systematically searched PubMed, Cochrane Central, Scopus, ClinicalTrials.Gov, MEDLINE and Web of Science from September 2010 to September 2020 for our search terms. We included studies that specifically enrolled patients undergoing power morcellation myomectomy or power morcellation hysterectomy procedures. In our search, we had no restriction to age, country, or publication date.

We extracted data related to study design, baseline characteristics of patients, and perioperative outcomes such as total operative time, total blood loss, and duration of hospital stay. We found no substantial difference in total operative time between contained power morcellation and uncontained manual morcellation myomectomy $(\mathrm{p}=0.52)$, but contained power morcellation had a significantly longer total operative time than uncontained power morcellation for hysterectomy and myomectomy [135.50 vs. 93.33 minutes, ( $\mathrm{p}=0.003)$ ]. Total blood loss was comparable for contained power morcellation versus uncontained manual morcellation myomectomy $(\mathrm{p}=0.32)$ and contained power morcellation versus uncontained power morcellation myomectomy or hysterectomy $(\mathrm{p}=0.91)$. Contained power morcellation and uncontained manual morcellation myomectomy had comparable hospital stay periods ( $\mathrm{p}=0.5$ ). Contained power morcellation leads to a longer operating time than uncontained power morcellation for both hysterectomy and myomectomy. No differences were found in comparisons of blood loss, operative time, or comparison to manual methods of morcellation.
\end{abstract}

Keywords: Power morcellation, manual morcellation, myomectomy, meta-analysis

Öz

Contained morselasyon için yeni sistemler geliştirilmiş olduğundan; biz bu çalışmada miyom ve rahim morselasyonu için uygulanan contained ve uncontained tekniklerdeki olası farklılıklara ilişkin mevcut tüm yüksek kaliteli çalışmaları analiz etmeye çalıştık.

Arama terimlerimiz için Eylül 2010'dan Eylül 2020'nin sonuna kadar PubMed, Cochrane Central, Scopus, ClinicalTrials.Gov, MEDLINE ve Web of Science'yi sistematik olarak taradık. Power morselasyon miyomektomisi veya power morselasyon histerektomisi prosedürleri uygulanan hastaları özel olarak kaydeden çalışmalanı dahil ettik. Araştırmamızda yaş, ülke veya yayın tarihi ile ilgili herhangi bir kısıtlamamız yoktu. Çalışma tasarımı, hastaların temel özellikleri ve toplam ameliyat süresi, toplam kan kaybı ve hastanede kalış süresi gibi perioperatif sonuçlarla ilgili verileri çıkardık. Contained power morselasyon ve uncontained manuel morselasyon miyomektomisi $(\mathrm{p}=0,52)$ arasında toplam ameliyat süresi açısından anlamlı bir fark bulamadık, ancak histerektomi ve miyomektomi için contained power morselasyon uncontained power morselasyona göre daha uzun toplam ameliyat süresine sahipti [135,50

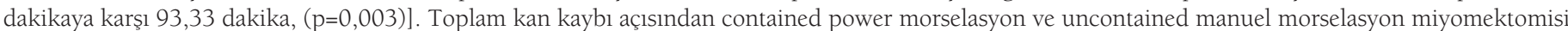
arasında $(\mathrm{p}=0,32)$ ve contained power morselasyon ile uncontained power morselasyon miyomektomisi veya histerektomisi arasında ( $\mathrm{p}=0,91)$ fark yoktu. Hastanede kalış süresi açısından, contained power morselasyonu ve uncontained manuel morselasyon miyomektomisi benzer sonuçlara sahipti (p=0,5).

Address for Correspondence/Yazışma Adresi: Greg Marchand MD, Marchand Institute for Minimally Invasive Surgery, Mesa, Arizona, USA Phone: +4809990905 E-mail: gm@marchandinstitute.org ORCID ID: orcid.org/0000-0003-4724-9148

Received/Geliş Tarihi: 23.08.2021 Accepted/Kabul Tarihi: 30.10.2021

${ }^{\circledR}$ Copyright 2021 by Turkish Society of Obstetrics and Gynecology

Turkish Journal of Obstetrics and Gynecology published by Galenos Publishing House 
Hem histerektomi hem de miyomektomi için contained power morselasyon, uncontained power morselasyona kıyasla daha uzun ameliyat süresi ile ilişkili gibi görünmektedir. Manuel morselasyon yöntemleri arasında kan kaybı ve ameliyat süresi açısından hiçbir fark bulunmadı.

Anahtar Kelimeler: Power morselasyon, manuel morselasyon, miyomektomi, meta-analiz

\section{Introduction}

Uterine fibroids or myomas are some of the most common benign tumors of premenopausal women ${ }^{(1)}$. Patients may present with pain, abnormal uterine bleeding, pressure symptoms, or infertility ${ }^{(2,3)}$. The traditional approach to treat large uterine myomas involved abdominal myomectomy or hysterectomy. With the advent of minimally invasive laparoscopic techniques, there is a need for analysis of the different techniques for performing laparoscopic hysterectomy and myomectomy in the presence of large fibroids requiring some form of morcellation for removal( ${ }^{(4)}$. Some studies have shown that laparoscopic myomectomy, versus open myomectomy, may have higher success rates and fewer complications when performed on appropriately selected patients ${ }^{(5)}$. Further described advantages of laparoscopic myomectomy include less postoperative pain, faster recovery time, shorter hospital stay, and higher probability of maintaining reproductive function ${ }^{(6)}$.

In an attempt to solve the problems of specimen removal in laparoscopy, several techniques have been developed to break apart these tissues in order to deliver them through the small incisions that characterize laparoscopy, also known as morcellation. As a result, various techniques, such as laparoscopic power morcellation and manual morcellation have been developed for laparoscopic, vaginal, or mini-laparotomy (ML) use. These procedures can be performed with or without a specially designed bag to contain the shredded pieces which may result ${ }^{(7)}$. In unexpected malignancies, power morcellation can lead to the unintended spread of malignant cells. This has become of particular interest in recent years, as the contained power morcellation of unexpected leiomyosarcoma can result in spreading of the leiomyosarcoma and worsening of the patient's prognosis. This culminated in an Food and Drug Administration (FDA)-issued statement discouraging the use of power morcellation for myomectomy or hysterectomy in 2014, but this statement was later updated to allow the their usage only in a contained environment ${ }^{(8)}$. The FDA decision may have been a factor in pushing manufacturers of power morcellation devices to develop containment systems for avoiding cell spillage and unintentional implantation of malignant cells $s^{(9,10)}$. Prior to these events, contained laparoscopies in gynecology were mainly performed in ovarian cystectomy or oophorectomy to reduce the risk of dissemination of undetected malignant cells ${ }^{(11)}$. Currently, many studies have investigated the different outcomes of in-bag manual or power uterine morcellation and assessed new techniques to address the general drawbacks of morcellation $^{(12-14)}$

In this analysis, we aimed at evaluating the contained power morcellation technique and compare its perioperative outcomes with the uncontained power and manual morcellation procedures. Unfortunately, at this time, there is insufficient follow-up data to support the aim of this study, including the discovery of future occult malignancy outcomes. Therefore, our aim at this time is limited to the analysis of the perioperative outcomes of these procedures. Moreover, we were unable to consider the effects of differences in morcellation techniques, closure methods, or the effects of administered intraoperative medications, such as vasopressin.

\section{Materials and Methods}

We conducted and drafted this study according to the steps described in "Cochrane handbook for systematic reviews of interventions" and the "Preferred reporting items for systematic reviews and meta-analyses (PRISMA)" guidelines ${ }^{(15,16)}$.

\section{Search Strategy and Data Collection}

We searched the following electronic databases: PubMed, Cochrane Central, Web of Science, ClinicalTrials.Gov, MEDLINE and Scopus for all published studies up to September 1, 2020, published within the last 10 years (from September 1, 2011). We conducted our search using the following key terms: "Laparoscopy," "Celioscopy," "Peritoneoscopy," "Morcellation," "Fibroidectomy," "Myomectomy," and "Uterine Myomectomy." After removing duplicates using Endnote software, we screened all remaining citations for eligibility through two steps: First, screening the titles and abstracts and second, screening the full texts. We then included the studies matching our selection criteria. Moreover, we manually screened the references of the included studies for other related papers.

\section{Selection Criteria}

We included all studies that enrolled patients specifically undergoing power morcellation myomectomy or power morcellation hysterectomy. In our search, we had no restriction to age, country, or publication date. We excluded non-English studies, non-available studies, thesis, reviews, and individual case reports. We did not further sort included studies by selected techniques, closure methods, or intraoperative medications administered. All techniques of power morcellation or manual morcellation were assumed to be performed to the best of the ability of the surgeon, and other differences of technique, (with the exception of power vs. manual morcellation), were ignored.

\section{Data Extraction}

The following data was extracted:

1. Summary of the included studies and their elements such as study design, study arms, duration, number of patients, and conclusion. 
2. Baseline characteristics of the enrolled patients including age, body mass index (BMI), gravidity and parity, number of nulliparous participants, history of abdominal surgeries, myoma characteristics, and myoma symptoms of pain, infertility, or abnormal uterine bleeding.

3. Perioperative outcomes including total operative time (defined as initial incision to skin closure), morcellation preparation time (defined as any time delegated by the surgeon to prepare in order to perform morcellation), total morcellation time (defined as the total time declared by the surgeon as needed to perform the morcellation portion of the procedure), total blood loss, and duration of hospital stay.

4. Data required to complete our quality assessment (assessment of bias).

\section{Quality Assessment}

We assessed the quality of the included studies using the National Institute of Health (NIH) quality assessment tools ${ }^{(17)}$. The tool for observational cohort studies composed of 14 questions to assess the risk of bias and confounders, while the tool for case series composed of 9 assessment questions. Assessment questions included the judgment of the clarity of the study question, the definition of the study population, the participation rate, the specification of the study inclusion and exclusion criteria, the sample size justification, the outcome measurement process, the sufficiency of timeframe and followup period, the precise definition and validity of the exposure and outcome measures, multiple measurements of the exposure, blinding of the outcome assessor, the loss of follow-up rate, and the potential confounding variables. These questions were answered by "yes," "no," "not applicable," "cannot determine," or "not reported." Then, each study was attributed a score to judge the overall quality as either "good," "fair," or "poor."

\section{Data Synthesis and Analysis}

Statistical analyses were performed using the RevMan version 5.4 software. Continuous outcomes were analyzed as mean difference (MD) and standard error. Pooled results were reported as MD and 95\% confidence interval (CI) using the generic inverse-variance method under the random-effects model. We used I-squared and chi-squared statistics to assess heterogeneity among the studies. Indications of heterogeneity included $\mathrm{I}^{2}$ values of $\geq 50 \%$ with chi-square $\mathrm{p}$-values $<0.10$. In the case of heterogeneity, we resolved by performing a sensitivity analysis using the "leave-one-out" test. Some studies reported the results of myomectomy and hysterectomy patients as a single group, so the data from these studies were pooled and reported in a separate analysis.

\section{Results}

Literature Search and Characteristics of the Included Trials Our search obtained 525 studies (232 from PubMed, 184 from Scopus, 100 from WOS, and 9 from Cochrane). After removing 49 duplicates and 452 citations by title and abstract screening, there were 24 papers that entered full-text screening and were further refined according to our criteria to eventually reach

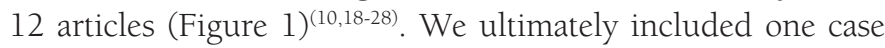
series and 11 cohort studies with 976 patients total. Among these, 714 patients underwent contained power morcellation, 213 underwent uncontained manual morcellation, and 49 underwent uncontained power morcellation. The mean age of the patients ranged from 31 to 49 years, and the mean BMI ranged from 22.2 to 32.1 across studies. A mean of $10 \%$ to $59 \%$ of patients among the studies had previous abdominal surgery and $18.5 \%$ to $65 \%$ of then had abnormal uterine bleeding. Summary of the included studies and baseline characteristics of the enrolled patients are found in Tables 1 and 2 respectively.

\section{Results of Quality Assessment}

According to the NIH quality assessment tool for observational cohort studies, all 11 included cohort studies were of fair quality ${ }^{(10,18-23,25-28)}$. According to the NIH quality assessment tool for case series, the included case series was of good quality $^{(29)}$. For more details on all assessment questions of each study, refer to Supplementary Table S1 for cohort studies and Supplementary Table S2 for the case series study.

\section{Study Outcomes}

\section{Total Operative Time (Min.)}

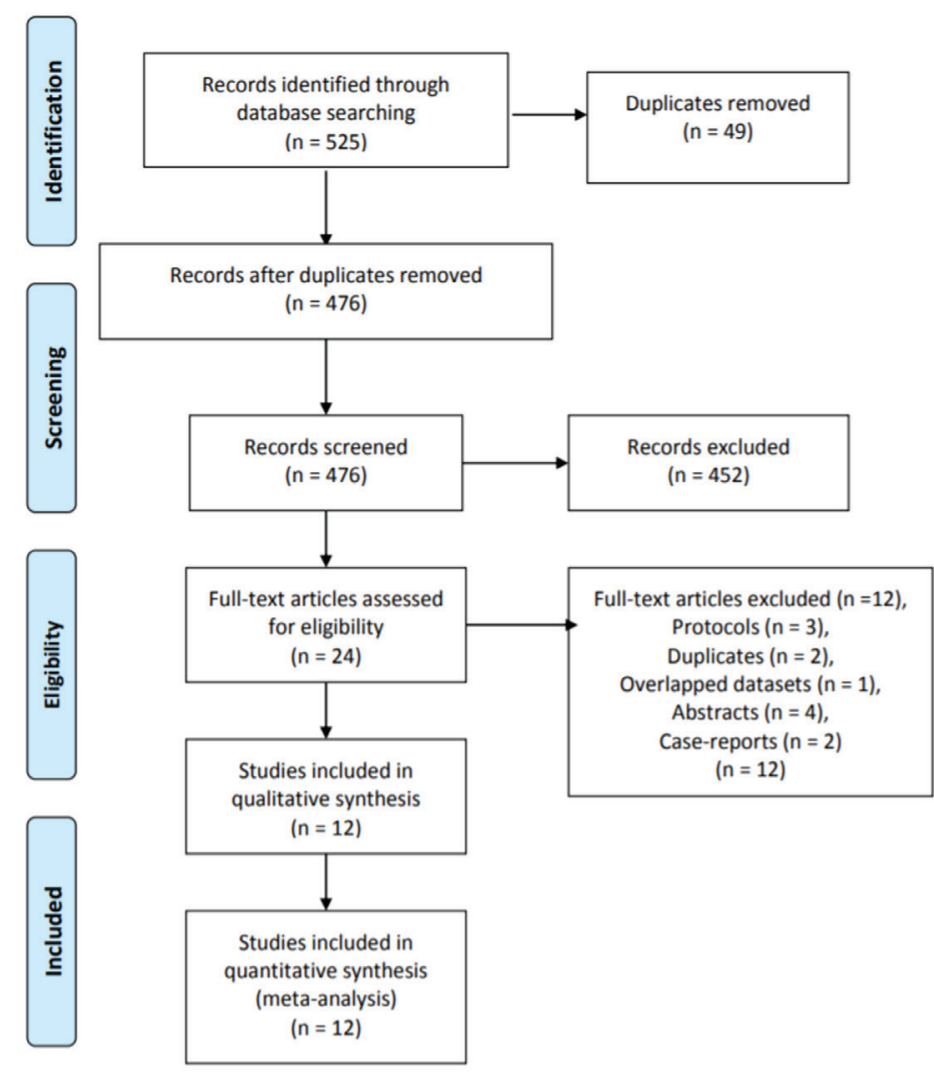

Figure 1. The PRISMA flow chart summarizing the literature search and including studies from each database

PRISMA: Preferred reporting items for systematic reviews and meta-analyses 
Table 1. Summary of the included studies

\begin{tabular}{|c|c|c|c|c|c|}
\hline Study ID & Patients & $\begin{array}{l}\text { Study } \\
\text { design }\end{array}$ & Duration & $\begin{array}{l}\text { Sample } \\
\text { size }\end{array}$ & Conclusion \\
\hline $\operatorname{Akdemir}^{(27)}$ & $\mathrm{CPM}$ & $\begin{array}{l}\text { Prospective } \\
\text { cohort }\end{array}$ & $\begin{array}{l}\text { January } 2014 \text { to } \\
\text { May } 2014\end{array}$ & 30 & $\begin{array}{l}\text { The innovative technique could prompt the usage of a } \\
\text { disposable latex glove for an enclosed morcellation that avoi } \\
\text { piercing the enclosure container within the abdominal cavit) } \\
\text { decreases the risks of bag perforation and leakage compared } \\
\text { with previous contained power morcellation techniques. }\end{array}$ \\
\hline Cohen $^{(18)}$ & CPM & $\begin{array}{l}\text { Prospective } \\
\text { cohort }\end{array}$ & 2014 to 2015 & 89 & $\begin{array}{l}\text { Findings are consistent with prior work (Cohen 2014) } \\
\text { demonstrating the feasibility of contained tissue extraction, } \\
\text { however further refinement of this technique is warranted. }\end{array}$ \\
\hline Cohen $^{(28)}$ & CPM & $\begin{array}{l}\text { Prospective } \\
\text { cohort }\end{array}$ & $\begin{array}{l}\text { January } 2014 \text { to } \\
\text { May } 2014\end{array}$ & 73 & $\begin{array}{l}\text { Morcellation within an insufflated isolation bag is a feasible } \\
\text { technique. }\end{array}$ \\
\hline
\end{tabular}

Single port transumbilical morcellation using a conventional electromechanical morcellator with or without a knife is

\begin{tabular}{|c|c|}
\hline $\operatorname{Kim}^{(20)}$ & CPM \\
\hline
\end{tabular}

feasible. Single port laparoscopic myomectomy is an alternative method with cosmetic advantage.

$\begin{array}{llll}\text { Paul }^{(29)} & \text { CPM } & \text { Case series } & \begin{array}{l}\text { November 2014 } \\ \text { to January 2015 }\end{array} \\ \text { Springborg }^{(21)} & \text { CPM } & \begin{array}{l}\text { Prospective } \\ \text { cohort }\end{array} & \begin{array}{l}\text { June 2014 to } \\ \text { September 2014 }\end{array}\end{array}$

In-bag morcellation using this new bag is a feasible technique of morcellating uterine myomas in a contained manner.

The presented improved contained morcellation technique is feasible in laparoscopic hysterectomy and myomectomy.

\section{CPM \&}

$\operatorname{Vargas}^{(19)}$

Uncontained power morcellation

Prospective cohort

November 2013 to April 2014

CPM \&

Won ${ }^{(22)}$ Uncontained manual morcellation

Retrospective cohort

December 2014 to December 2016

In-bag power morcellation results in perioperative outcomes comparable to the traditional laparoscopic approach. In this cohort, mean operative time was prolonged by 26 minutes within bag morcellation, but may potentially be reduced with further refinement of the technique.

In-bag power morcellation for SPA laparoscopic myomectomy is feasible and safe, minimizing the risks of open power morcellation. There were also no statistically significant differences in surgical outcomes.

Performing electromechanical power morcellation within the Espiner EcoSac 230 specimen bag was successfully performed in 187 patients with no bag-related complications. This method is feasible, reliable, and reproducible, even for a large specimen.

\section{CPM \&}

\begin{tabular}{|c|c|c|}
\hline Boza $^{(10)}$ & $\begin{array}{l}\text { Uncontained } \\
\text { manual }\end{array}$ & $\begin{array}{l}\text { Prospective } \\
\text { cohort }\end{array}$ \\
\hline
\end{tabular}
morcellation

$\begin{array}{lll}\text { Aoki }{ }^{(25)} \quad \text { CPM } & \begin{array}{l}\text { Retrospective } \\ \text { cohort }\end{array} & \begin{array}{l}\text { August } 2015 \text { to } \\ \text { October } 2015\end{array}\end{array}$

\section{CPM \&}

$\begin{array}{llll}\text { Trivedi }^{(26)} & \begin{array}{l}\text { Uncontained } \\ \text { manual }\end{array} & \begin{array}{l}\text { Retrospective } \\ \text { cohort }\end{array} & \text { May } 2012 \text { to } \\ \text { morcellation } & & \text { August } 2018\end{array}$

Both CPM and TVE can be used for safe retrieval of large myomas that are removed laparoscopically. Compared with CPM, TVE was associated with a shorter retrieval time, less postoperative pain, and less hospital costs.

Single-site in-bag morcellation performed with our new technique requires neither bag penetration nor piercing with a trocar and thus may prove beneficial for preventing spillage and dissemination of unwanted cells and tissue.

In myomectomy group both conventional and in-bag laparoscopic morcellation were comparable in terms of duration of the surgery and blood loss. When all cases (hysterectomy and myomectomy combined) and cases of hysterectomy with large fibroids were studied, laparoscopic in-bag morcellation difference in operative time. No case of leiomyosarcoma was found in our study of 720 cases of myomas or uterus with large myomas. took less operative time and there was statistically significant 


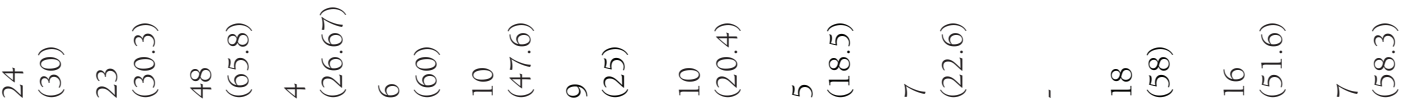

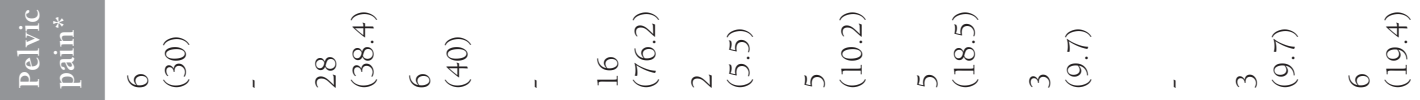

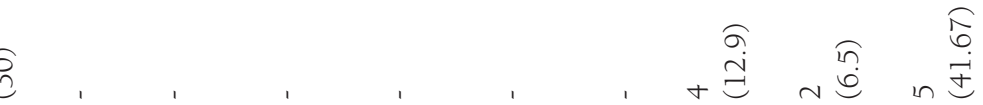

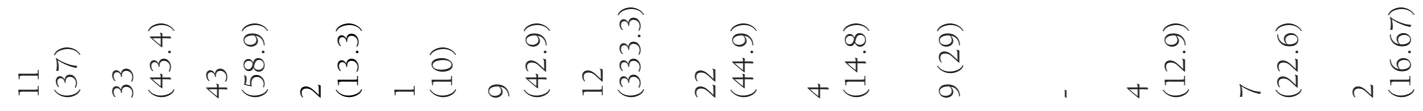

$\infty$

○导

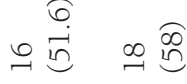

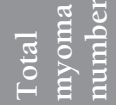

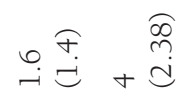

$a \stackrel{\text { in }}{ \pm}$

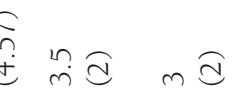

v $\underset{\mathfrak{b}}{\mathbb{d}}$

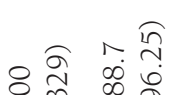

点

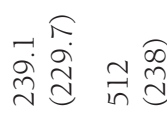

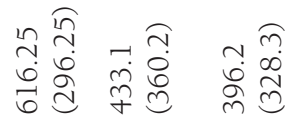

ठํㅟ $\stackrel{\infty}{\infty} \stackrel{0}{=}$

$\infty \stackrel{\sqrt[n]{n}}{\infty} \quad \infty \stackrel{\sqrt[n]{n}}{=}$

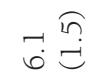

ำ

ำ

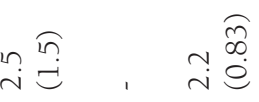

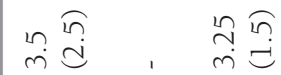

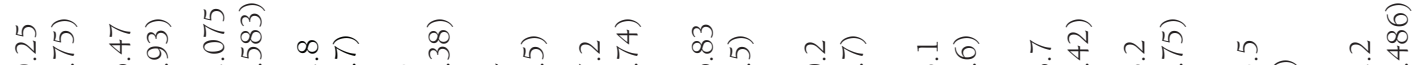

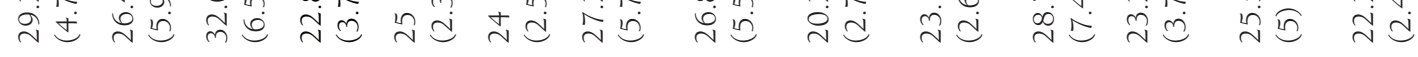

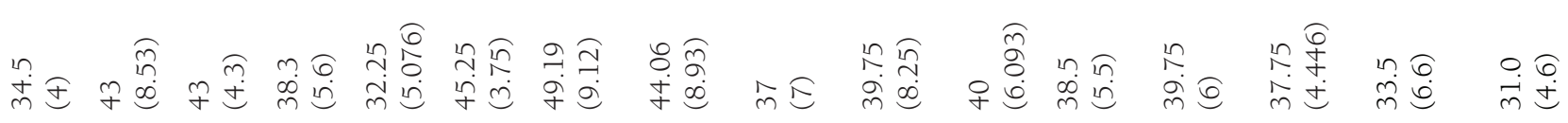

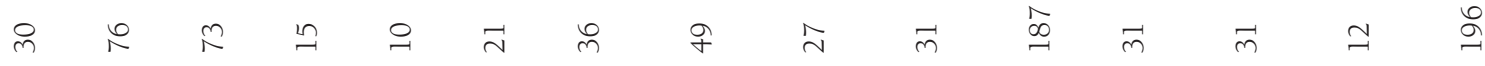

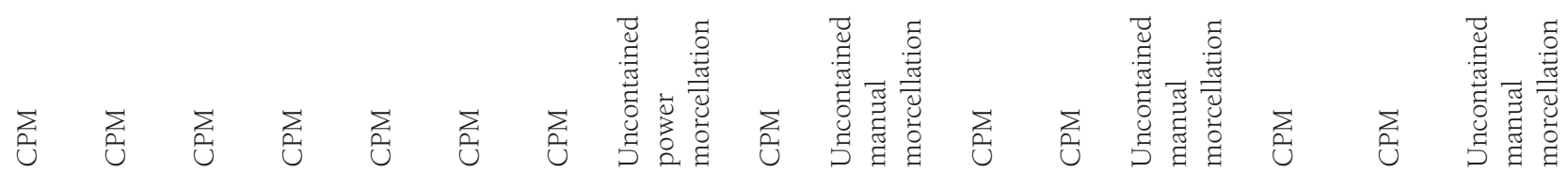

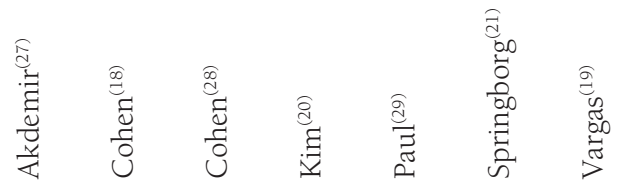

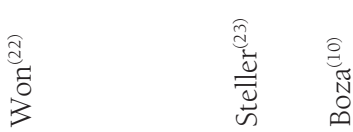

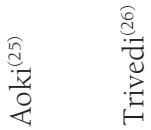




\subsection{Myomectomy-only data}

Six studies ${ }^{(10,22,26,27,29,30)}$ with analyzable data reported this outcome, with a total of 522 myomectomy patients; 309 patients underwent contained power morcellation, and 213 patients underwent uncontained manual morcellation. The pooled data showed an increase in total operative time in the contained power morcellation group $[\mathrm{MD}=116.66,95 \%$ CI $(102.38,130.93)]$ compared to the uncontained manual morcellation group [MD $=104.81,95 \%$ CI $(71.23,138.40)]$. There was no substantial differences in operative time between the two groups ( $\mathrm{p}=0.52$ ) (Figure 2 ).

The pooled results for both contained power morcellation $\left(\mathrm{p}<0.00001, \mathrm{I}^{2}=90 \%\right)$ and uncontained manual morcellation $\left(\mathrm{p}<0.00001, \mathrm{I}^{2}=97 \%\right)$ were heterogeneous, and could not be resolved.

\subsection{Hysterectomy and myomectomy data}

Five studies ${ }^{(18,19,21,25,28)}$ with analyzable data reported this outcome, with a total of 485 myomectomy or hysterectomy patients; 436 patients underwent contained power morcellation, and 49 patients underwent uncontained power morcellation. The pooled data showed an increase in total operative time for contained power morcellation [MD $=135.50,95 \%$ CI (110.23, 160.76)], over the uncontained power morcellation groups $[\mathrm{MD}=93.33,95 \% \mathrm{CI}(80.76,105.90)]$. The test for subgroup difference confirmed a statistically shorter operation time with the uncontained power morcellation ( $\mathrm{p}=0.003$ ) (Figure 3). The contained power morcellation subgroup was heterogeneous $\left(\mathrm{p}<0.00001, \mathrm{I}^{2}=92 \%\right)$, could not be solved and was not applicable to the other subgroup since it represented a single study arm.

\section{Morcellation Preparation Time (Min.)}

\subsection{Myomectomy-only data}

Two studies ${ }^{(27,29)}$ with analyzable data reported this outcome, with a total of 40 myomectomy patients all undergoing contained power morcellation. The results showed an average morcellation preparation time of 9.89 minutes $[95 \% \mathrm{CI}$

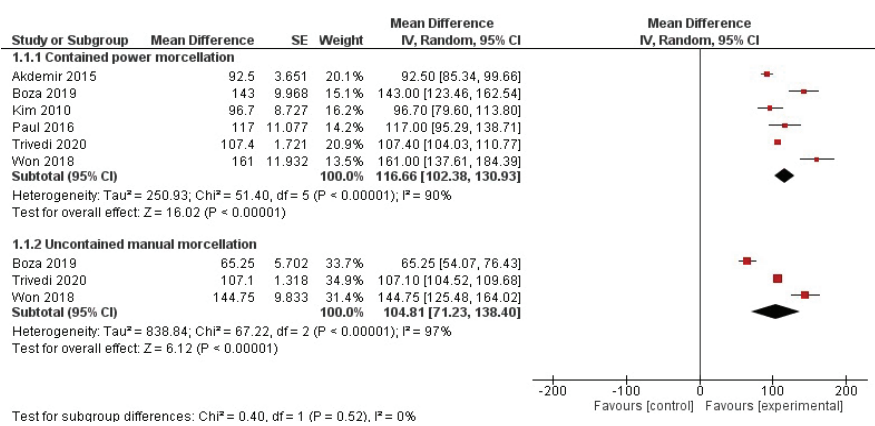

Figure 2. Forest plot of the total operative time (min.) comparison between contained power morcellation versus uncontained manual morcellation myomectomy

CI: Confidence interval
(5.12, 14.65)] (Supplementary Figure S1). Pooled data were heterogeneous ( $\mathrm{p}<0.0008, \mathrm{I}^{2}=91 \%$ ), and could not be resolved.

\subsection{Hysterectomy and myomectomy data}

Two studies ${ }^{(21,25)}$ with analyzable data reported this outcome, with 51 myomectomy or hysterectomy patients all undergoing contained power morcellation surgery. The results showed an average morcellation preparation time of 15.83 minutes [95\% CI $(4.26,27.39)$ ] (Supplementary Figure S2). Pooled data were heterogeneous ( $\mathrm{p}<0.00001, \mathrm{I}^{2}=96 \%$ ), and we could not solve the heterogeneity.

\section{Total Morcellation Time (Min.)}

\subsection{Myomectomy-only data}

Two studies ${ }^{(27,29)}$ with analyzable data reported this outcome, with 40 myomectomy patients who underwent contained power morcellation. The results showed an average morcellation time of 29.74 minutes, [95\% CI $(21.29,38.19)$ ] (Supplementary

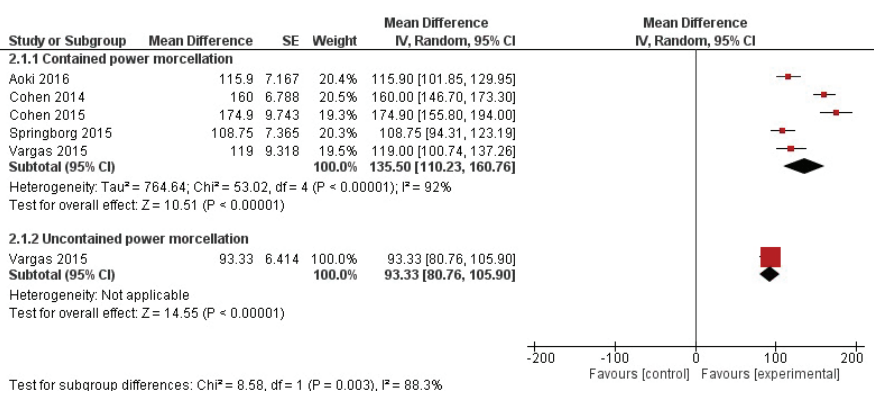

Figure 3. Forest plot of the total operative time (min.) comparison between contained power morcellation versus uncontained power morcellation myomectomy or hysterectomy

CI: Confidence interval

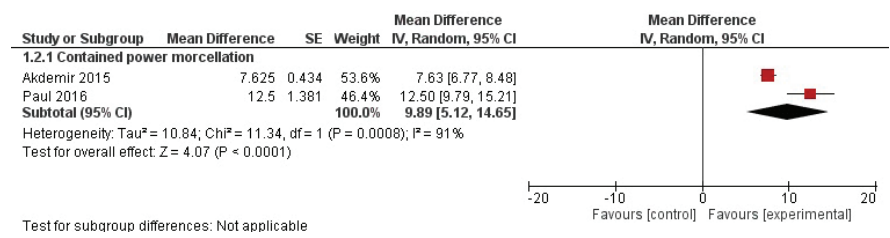

Supplemental Figure S1. Forest plot of the morcellation preparation time (min.) for contained power morcellation myomectomy

CI: Confidence interval

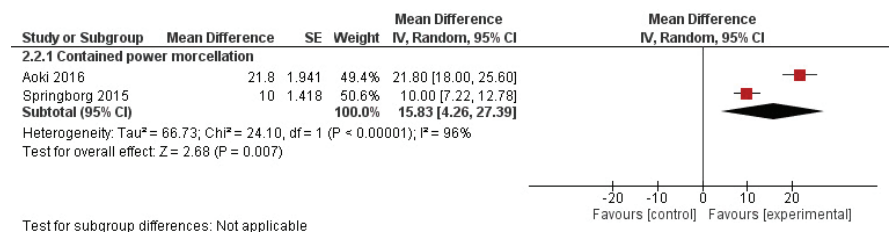

Supplemental Figure S2. Forest plot of the morcellation preparation time (min.) for contained power morcellation hysterectomy or myomectomy

CI: Confidence interval 
Figure S3). The data were heterogeneous $\left(\mathrm{p}<0.03, \mathrm{I}^{2}=78 \%\right)$, and we could not solve the heterogeneity.

\subsection{Hysterectomy and myomectomy data}

Two studies ${ }^{(18,25)}$ with analyzable data reported this outcome, with 119 myomectomy or hysterectomy patients who underwent contained power morcellation. The results showed an average morcellation time of 32.80 minutes, [95\% CI $(26.42,39.18)$ ] (Supplementary Figure S4). Pooled data were homogenous ( $\left.\mathrm{p}<0.16, \mathrm{I}^{2}=50 \%\right)$.

\section{Total Blood Loss (mL)}

\subsection{Myomectomy-only data}

Five studies ${ }^{(10,22,26,27,29)}$ with analyzable data reported this outcome, with 507 myomectomy patients; 294 patients underwent contained power morcellation, and 213 patients underwent uncontained manual morcellation. The pooled data showed an increase in total blood loss in the contained power morcellation group $[\mathrm{MD}=143.12$, 95\% CI (105.37, 180.87)] compared to the uncontained manual morcellation group $[\mathrm{MD}=111.32,95 \% \mathrm{CI}(62.06,160.59)]$. There was no difference in this outcome between the two groups $(\mathrm{p}=0.32)$ (Figure 4). Pooled data were heterogeneous for both contained power morcellation $\left(\mathrm{p}<0.00001, \mathrm{I}^{2}=92 \%\right)$ and uncontained manual morcellation $\left(p<0.00001, I^{2}=97 \%\right)$, and we could not solve the heterogeneity.

\subsection{Hysterectomy and myomectomy data}

Six studies $(18,19,21,23,25,28)$ with analyzable data reported this outcome, with 485 myomectomy or hysterectomy patients; 436 patients underwent contained power morcellation, and 49 patients underwent uncontained power morcellation. The pooled data showed an increase in total blood loss in the contained power morcellation group [MD $=119.62,95 \%$ CI $(85.28,153.96)]$ compared to the uncontained power

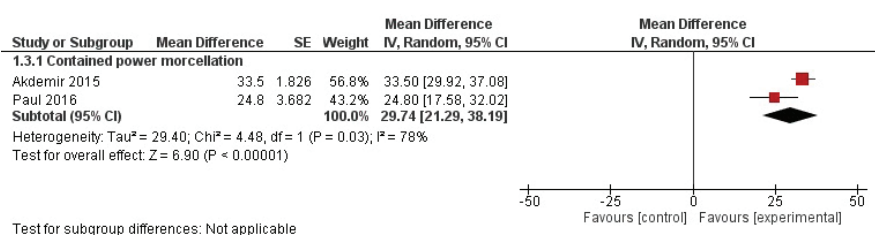

Supplemental Figure S3. Forest plot of the total morcellation time (min.) for contained power morcellation myomectomy

CI: Confidence interval

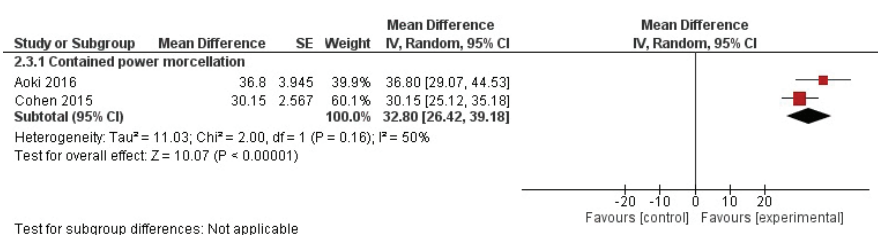

Test for subaroun differences: Not applicable

Supplemental Figure S4. Forest plot of the total morcellation time (min.) for contained power morcellation hysterectomy or myomectomy morcellation group [MD=116.10, 95\% CI $(62.14,170.06)]$. The test for subgroup difference showed no difference between the two groups $(\mathrm{p}=0.91)$ (Figure 5). The data for the contained power morcellation subgroup was heterogeneous ( $\mathrm{p}<0.00001$, $\mathrm{I}^{2}=85 \%$ ), and we could not solve the heterogeneity, while heterogeneity did not apply to the uncontained power morcellation subgroup because it represented a single study arm.

\section{Duration of Hospital Stay (Days)}

\subsection{Myomectomy-only data}

Five studies ${ }^{(10,20,22,27,29)}$ with analyzable data reported this outcome, with 175 myomectomy patients; 113 patients underwent contained power morcellation, and 62 patients underwent uncontained manual morcellation. The pooled data showed an increase in the duration of hospital stay in the contained power morcellation $[\mathrm{MD}=1.86,95 \% \mathrm{CI}(1.17,2.54)]$ over the uncontained manual morcellation groups $[\mathrm{MD}=2.10$, $95 \% \mathrm{CI}(1.86,2.35)]$. Both groups had comparable hospital stay duration $(\mathrm{p}=0.5)$ (Figure 6). Pooled data were heterogeneous for contained power morcellation $\left(p<0.00001, I^{2}=97 \%\right)$ and uncontained manual morcellation $\left(\mathrm{p}<0.12, \mathrm{I}^{2}=58 \%\right)$, and we could not solve the heterogeneity.

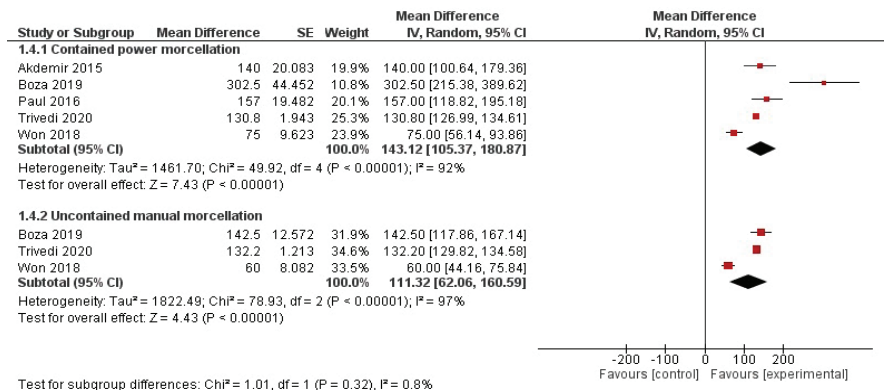

Figure 4. Forest plot of the total blood loss (mL) comparison between contained power morcellation versus uncontained manual morcellation myomectomy

CI: Confidence interval

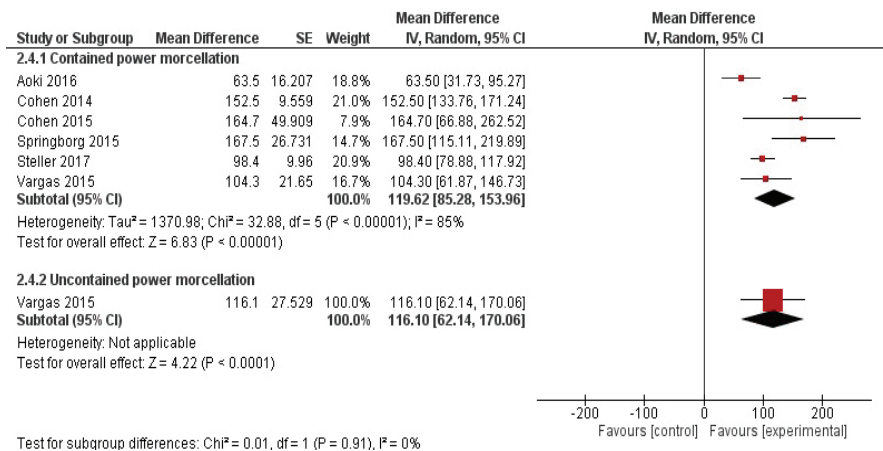

Figure 5. Forest plot of the total blood loss $(\mathrm{mL})$ comparison between contained power morcellation versus uncontained power morcellation myomectomy or hysterectomy

CI: Confidence interval 


\subsection{Hysterectomy and myomectomy data}

Two studies ${ }^{(21,28)}$ with analyzable data reported this outcome, with 94 myomectomy or hysterectomy patients who underwent contained power morcellation. Pooled data showed an average hospital stay duration of 0.74 days, [95\% CI $(0.25,1.23)$ ] (Figure 7). Pooled data were also heterogeneous ( $<<0.00001$, $I^{2}=95 \%$ ), and this could not be solved.

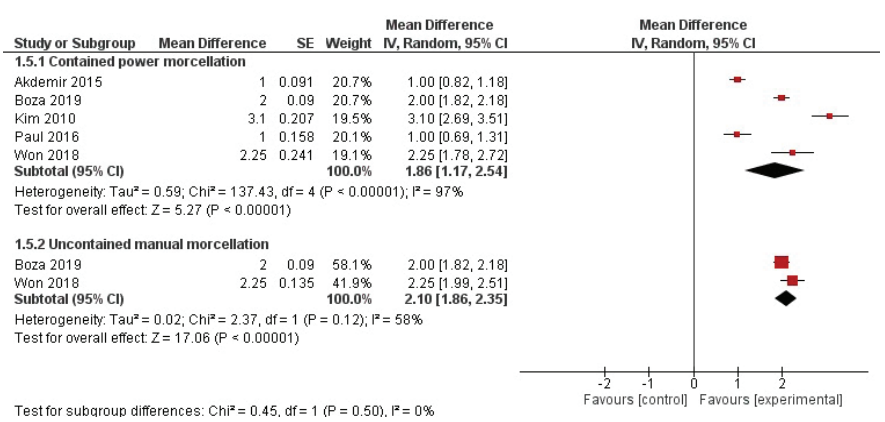

Figure 6. Forest plot of the duration of hospital stay (days) comparison between contained power morcellation versus uncontained manual morcellation myomectomy

CI: Confidence interval

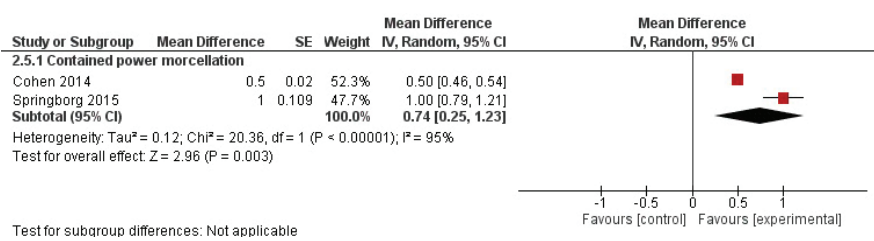

Figure 7. Forest plot of the duration of hospital stay (days) for contained power morcellation myomectomy or hysterectomy

CI: Confidence interval

\section{Discussion}

Contained power morcellation and uncontained power morcellation for myomectomy and hysterectomy had similar total blood loss, but uncontained power morcellation had a shorter total operative time for both procedures. Contained power morcellation and uncontained manual morcellation myomectomy had similar total operation time, total blood loss, and hospital stay duration. These findings confirm that contained power morcellation is a feasible procedure, but likely does involve an increase in operation time.

In $1979, \mathrm{Semm}^{(30)}$ reported the first laparoscopic myomectomy (LM), which aimed to minimize complications due to abdominal myomectomy or hysterectomy. Laparoscopy enabled surgeons to remove multiple myomas during one procedure ${ }^{(31,32)}$. Then morcellation emerged to overcome the limitations related to myoma size, making it possible to extract myomas reaching $20 \mathrm{~cm}$ or greater laparoscopically ${ }^{(33)}$. Morcellation approaches varied over time and several studies investigated different techniques, including in situ as well as incisional morcellation techniques $^{(34-38)}$.
A retrospective cohort study compared perioperative outcomes associated with electronic power morcellation (PM), manual vaginal morcellation, and manual morcellation via ML in 297 cases, including 137 myomectomies $^{(7)}$. They reported no significant differences between the techniques of the three morcellation methods, but the operative time was longer with the ML. Therefore, the three techniques are considered feasible options for LM.

The FDA statement largely precludes morcellation that is both uncontained and uses a power source, but it does not specifically discourage the use of techniques that exclude one or the other ${ }^{(8)}$. Therefore, there are confounding views as to whether PM should be used with containment or rather simply replaced with a manual method. A recent review concluded that different factors could correlate with sarcoma dissemination and also recommended PM use only in premenopausal women undergoing myomectomy, only after an endometrial biopsy was obtained ${ }^{(39)}$. A meta-analysis of 176 premenopausal women who underwent LM compared intraoperative and postoperative outcomes between in-bag PM and uncontained manual morcellation but no significant difference was found between the methods due to the low-quality evidence used ${ }^{(40)}$. Although PM is often criticized for possible injuries, it is worth mentioning that no intraoperative complications were reported in most of our included studies ${ }^{(21-23,25-27,29)}$. Also, the advantages of PM regarding cosmetic effect ${ }^{(20)}$ and easier management of large myoma ${ }^{(23)}$ are worth noting. Only two of the included studies reported no intraoperative complications with manual morcellation $^{(22,26)}$. Three intraoperative complications were reported in the included studies for contained ${ }^{(18,19)}$ and uncontained PM myomectomy or hysterectomy ${ }^{(19)}$.

Given that PM is discouraged without a containment system, different techniques are emerging to cope with available resources in low-income countries. For example, Akdemir et al. ${ }^{(27)}$ described the feasibility of using a surgical glove instead of an expensive bag for laparoscopic morcellation in Turkey.

\section{Strengths}

Our study is the first meta-analysis to compare contained PM with uncontained manual morcellation. We extracted all analyzable data and included all available observational studies with variations in sample sizes. The Cochrane handbook and PRISMA guidelines were followed throughout this manuscript. According to quality assessment tools, most included studies were of moderate quality.

\section{Study Limitations}

These include the observational design of included studies, the high heterogeneity that could not be solved in most outcomes, and the small sample size of some included studies. As a result, we were forced to perform an indirect analysis due to insufficient data for direct comparison. In addition, variations in surgical techniques, which could vary from surgeon to surgeon if not surgery to surgery, could introduce some error into our 
analysis. This could include the injection of vasoconstricting agents, or differences in tissue closure techniques. This would likely have the largest effect on the surgeon's operating time. There is a critical need for more well-designed randomized controlled trials with larger samples and more accurate measurements in order to determine the efficacy and safety of contained PM, in relation to various perioperative and postoperative outcomes. It would be particularly useful if future studies could investigate novel techniques used to practice contained morcellation and manage large myomas, and could include comparisons of intraoperative medications, such as vasopressin, which has the potential to significantly decrease blood loss and operative times.

\section{Conclusion}

Contained PM myomectomy has similar total operation time, total blood loss, and hospital stay duration compared with uncontained manual morcellation myomectomy. Also, it has similar total blood loss as uncontained PM for myomectomy or hysterectomy. However, contained PM seems to have a longer total operation time than uncontained PM.

\section{Ethics}

Peer-review: Internally peer-reviewed.

\section{Authorship Contributions}

Concept: A.K., G.M., A.M., A.C., G.B., K.S., Data Collection or Processing: A.C., G.B., H.U., A.A., S.G., J.P., C.C., Analysis or Interpretation: A.M., Tables: A.C., Figures: A.A., H.U., Supervision: S.R.

Conflict of Interest: No conflict of interest was declared by the authors.

Financial Disclosure: The authors declared that this study received no financial support.

\section{References}

1. Agdi M, Tulandi T. Minimally invasive approach for myomectomy. Semin Reprod Med 2010;28:228-34.

2. Acién P, Quereda F. Abdominal myomectomy: results of a simple operative technique. Fertil Steril 1996;65:41-51.

3. Pritts EA, Parker WH, Olive DL. Fibroids and infertility: an updated systematic review of the evidence. Fertil Steril 2009;91:1215-23.

4. Stringer NH, Walker JC, Meyer PM. Comparison of 49 laparoscopic myomectomies with 49 open myomectomies. J Am Assoc Gynecol Laparosc 1997;4:457-64.

5. Bean EM, Cutner A, Holland T, Vashisht A, Jurkovic D, Saridogan E. Laparoscopic myomectomy: a single-center retrospective review of 514 patients. J Minim Invasive Gynecol 2017;24:485-93.

6. Falcone T, Parker WH. Surgical management of leiomyomas for fertility or uterine preservation. Obstet Gynecol 2013;121:856-68.

7. Meurs E, Brito LG, Ajao MO, Goggins ER, Vitonis AF, Einarsson $\mathrm{JI}$, et al. Comparison of morcellation techniques at the time of laparoscopic hysterectomy and myomectomy. J Minim Invasive Gynecol 2017;24:843-9.

8. (FDA) TUSFaDA. UPDATE: The FDA recommends performing contained morcellation in women when laparoscopic power morcellation is appropriate. Last Accessed Date: 25.02.2020.
Available from: https://www.fda.gov/medical-devices/safetycommunications/update-fda-recommends-performingcontained-morcellation-women-when-laparoscopic-powermorcellation.

9. Cheung VY, Pun TC. Contained morcellation for laparoscopic myomectomy within a specially designed bag. J Minim Invasive Gynecol 2016;23:139-40.

10. Boza A, Misirlioglu S, Taskiran C, Urman B. Contained power morcellation versus transvaginal extraction for retrieval of laparoscopically removed myomas: a comparison of perioperative outcomes. Surg Innov 2019;26:72-6.

11. Smorgick N. Laparoscopic specimen retrieval bags. J Obstet Gynaecol India 2014;64:370-2.

12. Kho KA, Nezhat $\mathrm{CH}$. Evaluating the risks of electric uterine morcellation. JAMA 2014;311:905-6.

13. Rimbach S, Holzknecht A, Schmedler C, Nemes C, Offner F. First clinical experiences using a new in-bag morcellation system during laparoscopic hysterectomy. Arch Gynecol Obstet 2016;294:83-93.

14. AAGL Practice Report: morcellation during uterine tissue extraction. J Minim Invasive Gynecol 2014;21:517-30.

15. Higgins JP, Thomas J, Chandler J, Cumpston M, Li T, Page MJ, et al. Cochrane Handbook for Systematic Reviews of Interventions. New York: John Wiley \& Sons; 2019.

16. Liberati A, Altman DG, Tetzlaff J, Mulrow C, Gøtzsche PC, Ioannidis JP, et al. The PRISMA statement for reporting systematic reviews and meta-analyses of studies that evaluate health care interventions: explanation and elaboration. PLoS Med 2009;6:e1000100.

17. National Institute of Health National Heart, Lung and Blood Institute Quality Assessment Tools. Available from: https://www. nhlbi.nih.gov/health-topics/study-quality-assessment-tools.

18. Cohen SL, Morris SN, Brown DN, Greenberg JA, Walsh BW, Gargiulo AR, et al. Contained tissue extraction using power morcellation: prospective evaluation of leakage parameters. Am J Obstet Gynecol 2016;214:257.el-.e6.

19. Vargas MV, Cohen SL, Fuchs-Weizman N, Wang KC, Manoucheri E, Vitonis AF, et al. Open power morcellation versus contained power morcellation within an insufflated isolation bag: comparison of perioperative outcomes. J Minim Invasive Gynecol 2015;22:4338.

20. Kim YW, Park BJ, Ro DY, Kim TE. Single-port laparoscopic myomectomy using a new single-port transumbilical morcellation system: initial clinical study. J Minim Invasive Gynecol 2010;17:58792.

21. Springborg HH, Istre O. Complete plastic lining of the abdominal cavity during laparoscopic electromechanical morcellation-a promising technique. Gynecol Surg 2015;12:133-7.

22. Won YB, Lee HJ, Eoh KJ, Chung YS, Lee YJ, Park SH, et al. Inbag power morcellation technique in single-port laparoscopic myomectomy. Obstet Gynecol Sci 2018;61:267-73.

23. Steller C, Cholkeri-Singh A, Sasaki K, Miller CE. Power morcellation using a contained bag system. JSLS 2017;21:e2016.00095.

24. Paul PG, Khurd AS, Radhika KT, Bulusu S, Paul G. techniques for laparoscopic contained tissue extraction. Curr Obstet Gynecol Rep 2016;5:325-32.

25. Aoki Y, Matsuura M, Matsuno T, Yamamoto T. Single-site in-bag morcellation achieved via direct puncture of the pneumoperitoneum cap, a cordless electric morcellator, and a 5-mm flexible scope. Eur J Obstet Gynecol Reprod Biol 2016;201:126-30.

26. Trivedi PH, Trivedi S, Patil S. Laparoscopic in-bag morcellation compared with conventional morcellation of myomas and uterus with myomas. J Obstet Gynaecol India. 2020;70:69-77. 
27. Akdemir A, Taylan E, Zeybek B, Ergenoglu AM, Sendag F. Innovative technique for enclosed morcellation using a surgical glove. Obstet Gynecol 2015;125:1145-9.

28. Cohen SL, Einarsson JI, Wang KC, Brown D, Boruta D, Scheib SA, et al. Contained power morcellation within an insufflated isolation bag. Obstet Gynecol 2014;124:491-7.

29. Paul PG, Thomas M, Das T, Patil S, Garg R. Contained morcellation for laparoscopic myomectomy within a specially designed bag. J Minim Invasive Gynecol 2016;23:257-60.

30. Semm K. Tissue-puncher and loop-ligation--new aids for surgicaltherapeutic pelviscopy (laparoscopy) = endoscopic intraabdominal surgery. Endoscopy 1978;10:119-24.

31. Palomba S, Zupi E, Russo T, Falbo A, Marconi D, Tolino A, et al. A multicenter randomized, controlled study comparing laparoscopic versus minilaparotomic myomectomy: short-term outcomes. Fertil Steril 2007;88:942-51.

32. Seracchioli R, Rossi S, Govoni F, Rossi E, Venturoli S, Bulletti C, et al. fertility and obstetric outcome after laparoscopic myomectomy of large myomata: a randomized comparison with abdominal myomectomy. Hum Reprod 2000;15:2663-8.

33. Sinha R, Hegde A, Warty N, Patil N. Laparoscopic excision of very large myomas. J Am Assoc Gynecol Laparosc 2003;10:461-8.
34. Sinha R, Hegde A, Warty N, Mahajan C. Laparoscopic myomectomy: enucleation of the myoma by morcellation while it is attached to the uterus. J Minim Invasive Gynecol 2005;12:284-9.

35. Torng PL, Hwang JS, Huang SC, Chang WC, Chen SY, Chang DY, et al. effect of simultaneous morcellation in situ on operative time during laparoscopic myomectomy. Hum Reprod 2008;23:2220-6.

36. Chen SY, Chang DY, Sheu BC, Torng PL, Huang SC, Hsu WC, et al. Laparoscopic-assisted vaginal hysterectomy with in situ morcellation for large uteri. J Minim Invasive Gynecol 2008;15:559-65.

37. Zhang P, Song K, Li L, Yukuwa K, Kong B. Application of simultaneous morcellation in situ in laparoscopic myomectomy of larger uterine leiomyomas. Med Princ Pract 2011;20:455-8.

38. Tsai HW, Ocampo EJ, Huang BS, Twu NF, Wang PH, Yen MS, et al. effect of semisimultaneous morcellation in situ during laparoscopic myomectomy. Gynecol Minim Invasive Ther 2015;4:132-136.

39. Halaska MJ, Gracia M, Laky R, Zapardiel I. Morcellation of the uterus: is there any place? Curr Oncol Rep 2020;22:68.

40. Zullo F, Venturella R, Raffone A, Saccone G. In-bag manual versus uncontained power morcellation for laparoscopic myomectomy. Cochrane Database Syst Rev 2020;5:CD013352. doi: 10.1002/14651858.CD013352.pub2.

Supplementary Table S1. Risk of bias assessment of the included cohort studies

\begin{tabular}{|c|c|c|c|c|c|c|c|c|c|c|c|c|c|c|c|}
\hline ID & 1 & 2 & 3 & 4 & 5 & 6 & 7 & 8 & 9 & 10 & 11 & 12 & 13 & 14 & Score \\
\hline Cohen, 2015(18) & Yes & Yes & Yes & Yes & No & Yes & No & Yes & Yes & No & Yes & No & No & No & 10 \\
\hline Kim, 2010(20) & Yes & Yes & Yes & Yes & No & Yes & No & No & Yes & No & Yes & No & No & No & 10.5 \\
\hline Springborg, $2015^{(21)}$ & Yes & Yes & Yes & Yes & No & Yes & No & Yes & Yes & No & Yes & No & No & No & 11 \\
\hline Won, 2018 (22) & Yes & Yes & Yes & Yes & No & Yes & No & No & Yes & No & Yes & No & No & No & 11.5 \\
\hline Steller, $2017^{(23)}$ & Yes & Yes & Yes & Yes & Yes & Yes & No & Yes & Yes & No & Yes & No & No & No & 11.5 \\
\hline Boza, $2019^{(10)}$ & Yes & Yes & Yes & Yes & Yes & Yes & Yes & No & Yes & No & Yes & No & No & No & 11.5 \\
\hline Aoki, 2016 (25) & Yes & Yes & Yes & Yes & No & Yes & No & Yes & Yes & No & Yes & No & No & No & 10.5 \\
\hline Trivedi, $2019^{(26)}$ & Yes & Yes & Yes & Yes & Yes & Yes & Yes & Yes & Yes & No & Yes & No & No & No & 11.5 \\
\hline
\end{tabular}

1: Was the research question or objective in this paper clearly stated?

2: Was the study population clearly specified and defined?

3: Was the participation rate of eligible persons at least $50 \%$ ?

4: Were all the subjects selected or recruited from the same or similar populations (including the same time period)? Were inclusion and exclusion criteria for being in the study prespecified and applied uniformly to all participants?

5: Was a sample size justification, power description, or variance and effect estimates provided?

6: For the analyses in this paper, were the exposure(s) of interest measured prior to the outcome(s) being measured?

7: Was the time frame sufficient so that one could reasonably expect to see an association between exposure and outcome if it existed?

8: For exposures that can vary in amount or level, did the study examine different levels of the exposure as related to the outcome (e.g., categories of exposure, or exposure measured as continuous variable)?

9: Were the exposure measures (independent variables) clearly defined, valid, reliable, and implemented consistently across all study participants?

10: Was the exposure(s) assessed more than once over time?

11: Were the outcome measures (dependent variables) clearly defined, valid, reliable, and implemented consistently across all study participants?

12: Were the outcome assessors blinded to the exposure status of participants?

13: Was loss to follow-up after baseline $20 \%$ or less?

14: Were key potential confounding variables measured and adjusted statistically for their impact on the relationship between exposure(s) and outcome(s)? 
Supplementary Table S2. Risk of bias assessment of the included case series study

\begin{tabular}{|l|l|l|l|l|l|l|l|l|l|l|l|}
\hline ID & 1 & 2 & 3 & 4 & 5 & 6 & 7 & 8 & 9 & Score \\
Paul, 2015(29) & Yes & Yes & Yes & Yes & Yes & Yes & No & Yes & Yes & 8
\end{tabular}

1. Was the study question or objective clearly stated?

2. Was the study population clearly and fully described, including a case definition?

3 . Were the cases consecutive?

4. Were the subjects comparable?

5. Was the intervention clearly described?

6. Were the outcome measures clearly defined, valid, reliable, and implemented consistently across all study participants?

7. Was the length of follow-up adequate?

8. Were the statistical methods well-described?

9. Were the results well-described? 